\title{
Unde malum? \\ Kreacja bohatera negatywnego \\ z perspektywy \\ dziewiętnastowiecznych pseudonauk \\ (Wiry Henryka Sienkiewicza)
}

DOI: http://dx.doi.org/10.12775/LC.2019.042

iry zajmują szczególne miejsce w zbiorze dzieł Henryka Sienkiewicza. Jest to ostatnia jego powieść, którą ukończy11. Wydana za życia pisarza, w roku 1910, napisana niejako na zamówienie Narodowej Demokracji (Tyszka 2007: 289), już w pierwotnym zamyśle miała posłużyć jako ważny głos krytyki rewolucji 1905 roku. Twórca uważał, że popierający rewolucję Polacy nie mogą nazywać się prawdziwymi patriotami; ich działania miały być efektami rusyfikacji (ibid.: 291) i syjonistycznego spisku².

Podobną wymowę ideologiczną ma także powieść. Warstwa szlachecka, ukazana tutaj komiksowo, niczym bohaterowie Pana Tadeusza spędza czas głównie na wspólnych posiłkach, przejażdżkach, koncertach i praktykach religijnych, które wydają się pozbawione

Doktorantka na Wydziale Filologicznym Uniwersytetu Gdańskiego. Zajmuje się badaniem twórczości Henryka Sienkiewicza.

E-mail:mrozkat@wp.pl.

W przeciwieństwie do nieukończonych, równie późnych Legionów, w której to powieści historycznej autor przedstawił epizody z walk legionów polskich w kampanii napoleońskiej. Powieść była publikowana na łamach "Tygodnika llustrowanego" od 6 grudnia 1913 do 1 sierpnia 1914 roku. Pierwsze wydanie książkowe ukazało się dopiero w 1918 roku.

2 Wypowiedzi Sienkiewicza o charakterze antysemickim można znaleźć przede wszystkim w jego korespondencji do bliskich, zob. Burdziej 2010 . 
głębi ${ }^{3}$. Narrator jednak wartościuje pozytywnie sfery życia, w których obraca się klasa wyższa, akcentując ich kulturową stałość i przewidywalność. To, co wypracowane i wyuczone przez wieki, jest tutaj wartością, a największą rzeczniczką konserwatyzmu okazuje się pani Krzycka, matka Władysława, głównego bohatera powieści.

Wiry ukazują zarazem zasadniczą nieprzenikalność obu światów: szlacheckiego i chłopskiego. Nie ma pomiędzy tymi dwiema klasami możliwości porozumienia, a przyczynę tego stanu upatrują przedstawiciele szlachty w kolektywnym wyrażaniu postulatów przez chłopów:

Na nieszczęście z nimi jest tak, że każdy pojedynczo wzięty bywa rozsądny i nawet rozumny, a gdy się do wszystkich razem gada, to jakbyś głową w mur bił [...]. Weź dziesięć tysięcy doktorów filozofii, a zrobi się z nich tlum rządzący się odruchami (W I 49)"

Sądy te, wyabstrahowane z rozmowy Krzyckiego z Grońskim, pojawiają się w powieści w momencie, gdy chłopi z wioski Rzęślewo podważają testament ich pana, szlachcica Żarnowskiego. Utrzymują oni, że ziemie folwarczne po śmierci pana należą się im, a „testament jest fałszywy" (W I 48-49).

Jak się okazuje, przekonanie takie ugruntowało się wśród nich za sprawą niejakiego Laskowicza ${ }^{5}$, guwernera młodszego brata Władysława Krzyckiego, Stasia. Laskowicz jest studentem medycyny, wiadomo, że w Jastrzębiu przebywa od około pół roku.

Rozmowa Krzyckiego, Grońskiego i Dołhańskiego na jego temat jak w soczewce skupia problemy nurtujące różne warstwy polskiego społeczeństwa. Narrator Sienkiewicza niejednokrotnie podkreśla bowiem w Wirach niemożność porozumienia między szlachtą a klasami nieuprzywilejowanymi:

- [... ] dotychczas przypuszczałem, że można być socjalistą i mieć klepki w porządku ...

- A! Więc to ptak z tego g niazda? [podkr. K. M.] Powiedz mi [...], co to za figura?

- [...] Potrzebowaliśmy nauczyciela dla Stasia, ktoś go nam polecił. Powiedziano nam, że musi wyjechać na jakiś czas z Warszawy, by zejść z oczu policji - i oczywiście przyjąłem go tym skwapliwiej myśląc, że tu chodzi o jakie sprawy patriotyczne. Później, gdy się już pokazało, że to c a łk i e m in ny g at u n e k [podkr. K. M.], matka nie pozwoliła mi go jednak oddalić, wnadziei, że go nawróci... Brała go z początku na długie, serdeczne rozmowy, a mnie poleciła przyjaźnić się z nim. Traktowaliśmy go jak członka rodziny, a wynik był taki, że on nienawidzi nas nie tylko jako ludzi należących do nienawistnej mu sfery, ale zdaje się, że i osobiście (W I 38).

Bohaterowie pokazują jasno, że tylko te wartości, które sami wyznają, są ich zdaniem godne kultywowania. Ich naruszenie jest odbierane przede wszystkim jako aberracja, możliwa do zniwelowania za pomocą perswazji i prób wkupienia się w łaski obcego człowieka.

\footnotetext{
${ }^{3}$ Bezrefleksyjność i dewocyjność mieszkańców dworu w Jastrzębiu paradoksalnie są przedmiotem zazdrości Grońskiego, który czuje się przytłoczony wątpliwościami na polu religijnym i niejednokrotnie daje wyraz tęsknocie do przyjmowania wszystkiego na wiarę, bez uprzedniej weryfikacji. Zob. np. Łapiński 2016: 255 .

${ }_{4}^{4}$ Wszystkie cytaty według wydania: H. Sienkiewicz, Wiry, Gdańsk 1990. Tytuł oznaczam skrótem W, po którym podaję nr tomu oraz stronę.

${ }^{5}$ Laskowicz funkcjonuje w powieści jako „młody student medycyny". Pomijanie jego imienia przez narratora i bohaterów świadczy o poczuciu wyższości wobec niego. Podobną praktykę obserwuje się w Ogniem i mieczem - Bohun tylko raz jest zawołany w tej powieści po imieniu.
} 
Jedyny powód, dla którego przyzwoity człowiek mógłby, ich zdaniem, mieć problemy $\mathrm{z}$ wymiarem prawa, to konspiracja w celach patriotycznych, rozumiana jako przygotowanie kolejnego powstania ${ }^{6}$. Tym, że największe powstania XIX wieku - listopadowe i styczniowe - zakończyły się klęską, zdają się w ogóle nie przejmować. Nie potrafią wyobrazić sobie odmiennego modelu postępowania niż wszczęcie walki narodowowyzwoleńczej, a wszelkie inne warianty aktywności prowadzącej do zmian pozycji politycznej Polaków - jak akces wielu młodych ludzi w szeregi partii i jawne opowiadanie się za rewolucją - uważają za sprzeniewierzenie się ideałom patriotyzmu i sabotaż dotychczasowych działań przeciw zaborcy.

Szlachta uważa się za warstwę wysublimowanych indywidualistów, o czym świadczą słowa Dołhańskiego, wyjaśniającego przyczynę odrazy Laskowicza do elit:

Ma wam za złe, że nie jesteście tacy, jak was sobie wyobrażał, to jest ani tak źli, ani tak głupi. I możecie być pewni, że wam tego nigdy nie wybaczy (W I 38).

Krzycki kwituje tę diagnozę oschle:

Może być. W każdym razie będzie on nas wkrótce nienawidził z daleka, bo się za miesiąc rozstajemy. Rozumiem, że można i należy tolerować wszelkie przekonania, ale jest w nim przy tym, obok jego zasad i nienawiści, coś tak przeciwnego naszym wszystkim zwyczajom i c o ś ta k o b c e g o [podkr. K. M.], że mamy go już dosyć (W I 38).

Jak widać, nie tylko Laskowicz ma przed oczyma uproszczony obraz grupy, z którą usiłuje walczyć. Również szlachta nie zadaje sobie trudu, by spróbować zrozumieć pobudki działania socjalistów; generalizuje, tworząc opinię na ich temat na podstawie samych negatywów. Wypowiedź Krzyckiego dowodzi, że idee tolerancji nie zostały przez tę warstwę należycie przyswojone. Bohater poświadcza wprawdzie, iż „rozumie”, że „można i należy tolerować wszelkie przekonania”, ale dobitnie akcentuje obcość studenta i jego nieprzystawalność do obyczajów panujących w tej grupie społecznej.

$\mathrm{Na}$ tym etapie narracji czytelnik nie zna jeszcze dokładnie poglądów samego Laskowicza; widzi jedynie, że jego chlebodawcy nie zadali sobie trudu, aby wdać się z nim w dyskusję i go wysłuchać; jakakolwiek rozmowa była w istocie monologiem nasyconym argumentami mającymi dowodzić racji strony przeciwnej.

Protekcjonalny - i w końcu wrogi - stosunek do guwernera okazywany przez jego pracodawców i ich przyjaciół harmonizuje z postawą, jaką przyjmuje wobec niego narrator i najpewniej autor powieści. Widać to już od strony formalnej: Laskowicz jest ukazany jako postać statyczna i jednowymiarowa, zdefiniowana od początku jako typ (zob. Markiewicz 1981: 157), czarny charakter. Sposób jego przedstawienia, a co za tym idzie także oceny pozwalają mówić, iż głównie ten bohater symbolicznie wciela niepokój narratora (i autora) powieści co do sensu i skutków rewolucji, a tym samym jej krytyczny ogląd.

Sympatyzowanie $\mathrm{z}$ socjalistami (a nawet gorąca wiara $\mathrm{w}$ ich projekty i popularyzowanie ich z głębokim przekonaniem) to nie jedyna wina, jaką Laskowicz ma na sumieniu. Narrator konsekwentnie buduje jego negatywny obraz. Jego poglądy polityczne to zaledwie

\footnotetext{
6 Taką wymowę ma prawie nieznana nowela Sienkiewicza We mgle, wydana w 1920 roku.
} 
kamyczek rozpętujący lawinę złych uczynków. Ponieważ Wiry to powieść antyrewolucyjna, również bohater opowiadający się za przewrotem musi być zepsuty do szpiku kości.

Tak więc leżąc w łóżku i bezskutecznie usiłując zasnąć, student oddaje się niewysublimowanym fantazjom erotycznym inspirowanym postacią nieletniej Maryni Zbyłtowskiej, utalentowanej skrzypaczki. Jego chęć zdobycia dziewczyny wiąże się wyraźnie z pragnieniem użycia władzy. Zamierza uwieść skrzypaczkę, by ściągnąć ją do własnej sfery, w niziny społeczne - poniżenie młodocianej artystki miałoby być aktem deprecjacji kasty, z której ona się wywodzi. Laskowicz zamierza ją zatem zbrukać nie tylko pozbawieniem dziewictwa - jak już powiedziano, wszelkie zabiegi o charakterze erotycznym miałyby być jedynie środkiem do celu?.

Rzecz tu nie tylko w tym, że obiektem pożądania mężczyzny jest kobieta znacznie od niego młodsza (dwuznaczny charakter relacji męskich bohaterów z nastolatkami, jak również specyficzną postawę narratora wobec nich dostrzegł w powieściach Sienkiewicza już choćby Ryszard Koziołek - 2010: 225). Chodzi tu też o dostrzeganie w bohaterce jedynie cielesności, tj. sfery wartościowanej w kulturze chrześcijańskiej negatywnie. Laskowicz spogląda na nią „jak anatom” (W I 31) i choć czuje, że „jest w tym coś brutalnego”, sprawia mu to przyjemność. Lustruje ją tak podczas koncertu zorganizowanego dla gości przebywających w Jastrzębiu. Marynia gra tam przepisaną na skrzypce Sonatę Księżycowa Beethovena ${ }^{8}$, akompaniuje jej na flecie leciwy rejent Dzwonkowski, jej platoniczny wielbiciel.

Marynia jest uwielbiana przez każdego, kto się z nią zetknie, dzięki swej młodzieńczej świeżości i naiwności, a szczególną adoracją, zaraz po Dzwonkowskim, zdaje się darzyć ją Groński. Oni jednak, w porównaniu z Laskowiczem, nie mają skłonności sadystycznych. W zakresie zachowań służących erotycznej ekspresji mieszczą się w świecie przedstawionym Wirów wszelkiego rodzaju platoniczne uwielbienia (zarówno naznaczone cierpieniem z powodu niemożności zdobycia ukochanego obiektu, jak w przypadku Laskowicza i służącej panny Anney, Polci, jak i mniej dramatyczne, bliższe podziwowi, jak wspomniane już „adoracje” Grońskiego i Dzwonkowskiego); nieaprobowane, ale w pewnym sensie zrozumiałe jest sypianie pana z chłopkami (jak widać to w przypadku Krzyckiego i Hanki Skibianki). Poza tą normą mieszczą się w zasadzie jakiekolwiek oznaki erotycznej ekspresji bohaterek, w tym szczególnie podejmowanie przez nie współżycia przed ślubem (Hanka, choć jako chłopka chętnie spędzała noce z Krzyckim, później, jako bogata dziedziczka brytyjkkiego fabrykanta, należąca w pewnym sensie do klas uprzywilejowanych, odrzuca niedwuznaczne propozycje tego samego Krzyckiego, który został jej narzeczonym, i zrywa zaręczyny), a w przypadku bohaterów zasadniczo tylko wyraźnie określona przemoc (jak np. próba gwałtu) oraz parafilie zasługują na jednoznaczne potępienie?

\footnotetext{
7 Ten sposób działania czarnego charakteru został wykorzystany przez Sienkiewicza już w Ogniem i mieczem. Wystarczy przypomnieć sobie zabiegi Bohuna, który zamierzał przekupić wyżej urodzoną odeń Helenę, a zawarty z nią związek małżeński traktować jak przepustkę do świata możnych i szanowanych.

8 Utwór ten, nielubiany przez jego kompozytora, cieszy się szczególną atencją Sienkiewicza. Jego ekfraza pojawia się nie tylko na stronicach powieści o rewolucji, ale również na kartach Bez dogmatu. Być może wynika to z wielkiej sugestywności pierwszej części Beethovenowskiej sonaty, co ułatwia oddanie słowami ewokowanego przez nią nastroju. Jak można zaobserwować, muzyka pojawia się w tekstach Sienkiewicza stosunkowo rzadko, a i on sam nie czuł się kompetentny, by o niej pisać tak interesująco, jak robił to w przypadku sztuk plastycznych. Zob. Sobieraj 2004; Łobaczewska 1984.

9 Normy te przedstawiają się w taki sposób jedynie dla bohaterów heteroseksualnych, ponieważ dla narratora Sienkiewiczowskiego zjawisko homoseksualizmu w ogóle nie istnieje.
} 
Nie sposób wprawdzie jednoznacznie zawyrokować, czy Laskowicz cierpiał na konkretne zaburzenia preferencji seksualnych, jednakże zabiegi narratora wyraźnie zmierzają ku temu, by wykazać w psychice studenta „coś nienormalnego”. Znając kontekst epoki, można założyć, iż już zachowania autoerotyczne Laskowicza, wspomagane ogólnie zarysowanym marzeniem o Maryni, zasługiwałyby na określenie jako zboczenie. W metodzie pisarskiej Sienkiewicza nie mieści się opisywanie dosłownych fantazji i zachowań erotycznych bohatera. W tej sferze czytelnik często ma do czynienia z transpozycjami i niedomówieniami (Koziołek 2010: 131).

Zafascynowanie Laskowicza Marynią, które sam porównuje do stanu po zażyciu narkotyków (co wprowadza w sferę skojarzeń kolejną aktywność nieaprobowaną społecznie), podsuwa mu oryginalne metody kuszenia obiektu swych uczuć. Oto, marząc w łóżku o Zbyłtowskiej, Laskowicz próbuje wezwać dziewczynę do swego pokoju za pomocą hipnozy:

Przyjmując bezkrytycznie, a również i z całą przesadą właściwą fanatyzmowi i młodości wszystko, co książki podawały jako ostatnie wyniki badań lub zjawisk w dziedzinie naukowej, wierzył, iż hipnotyzm jest to tajemnicza i olbrzymia siła, która gdy może być zastosowana, staje się wówczas nieprzepartą. Mając się na mocy prób czynionych między kolegami za hipnotyzera i poczytawszy delikatną i wrażliwą panienkę za doskonałe medium, był najgłębiej przekonany, że może ją uśpić i rozkazywać z odległości. Sumienie szeptało mu wprawdzie, że to, co ma zamiar uczynić, jest nadużyciem nauki, ale on głuszył ów głos wmawiając w siebie, że to będzie jednocześnie zwycięstwo proletariusza nad tym światem, nad którym nie wolno mieć litości i że człowiek należący do obozu, który wypowiedział wojnę na śmierć i życie całej budowie społecznej i „przewartościował” wszelkie pojęcia będące dotychczas w obiegu, ma prawo i musi być bezwzględnym (W I 73-74).

Postawa narratora wobec opisywanej przez niego metody nie jest jednoznaczna. Początkowo zdaje się on traktować wiarę w działanie hipnozy jako wyraz infantylizmu, o czym świadczy wskazanie, że Laskowicz powoływał się na opinię kolegów, która była dla niego bardzo ważna. Takie zachowania są postrzegane jako naturalne w okresie dojrzewania. Stawianie znaku równości między lojalnością wobec grupy a wiarą w hipnozę oznacza, że ta ostatnia jest traktowana przez narratora jako coś, z czego się wyrasta. Ponieważ jednak Laskowicz jak dotąd z ufności w moc hipnozy nie wyrósł (a jest już studentem), należy spoglądać na ową „chorobę wieku dziecięcego” jak na zachowanie patologiczne. We fragmencie tym uderza jednak swego rodzaju zgoda narratora z Laskowiczem co do tego, że wykorzystanie hipnozy w celu, jaki student sobie założyl, stanowi nadużycie nauki. Świadczy o tym partykuła „wprawdzie”.

Zastanawia użycie w tym kontekście pojęcia „sumienie”. Laskowicz zetknął się z tym słowem najprawdopodobniej na drodze katolickiego wychowania, które otrzymał od matki będącej w bliskich związkach z Kościołem (W I 71). Później zapewne używał go w znaczeniu potocznym, bezrefleksyjnie. Interesujące, na ile automatycznie użył tego terminu narrator (i autor). Użycie pojęcia „sumienie” z rozmysłem wskazywałoby na to, że przyznaje on prawo ateistom do rozróżniania tego, co etyczne i moralne. Ponadto, wskazując wyraźny związek sumienia z nauką, podkreślałby wartość najważniejszą dla ludzi niewierzących w Boga - jest nią nauka. Dla Laskowicza i jemu podobnych, zdaniem narratora Wirów, to ona byłaby Bogiem, co stawiałoby bohatera w pozycji kogoś w rodzaju epigona 
pozytywizmu. Jak wynika z postawy życiowej Sienkiewicza, który na pewnym etapie swojego życia zaczął coraz silniej skłaniać się ku poglądom o konserwatywnym charakterze (zob. Krzyżanowski 1968: 110), wiara w nieskończone możliwości nauki nie może być wartościowana pozytywnie. Był autor Wirów, niczym Leon Płoszowski, „sceptycznym wobec własnego sceptycyzmu", co wyrażało się nie tyle w niepewności względem niesprawdzalności dogmatów wiary, ile w podejrzliwości wobec wszelkich deklaracji i pewników, obojętnie z jakiej dziedziny by one nie pochodziły.

Nie wszyscy podzielali taki pogląd; sama zaś postawa Laskowicza ma swoje źródło w rzeczywistości. W drugiej połowie XIX wieku wiara w nieskończoność poznania była wśród niektórych badaczy bardzo silna. Uważali, że wszystko da się zbadać i opisać naukowo; jeżeli z jakichś przyczyn zanalizowanie pewnych zjawisk okazuje się niemożliwe, oznacza to jedynie, iż wiedza na ich temat jest jak dotąd niedostateczna. Wśród polskich naukowców stanowisko takie zajmował Julian Ochorowicz (Nowak-Bobrowska 1971: 81), przyjaciel Prusa, pierwowzór Ochockiego w Lalce.

Ten badacz o wszechstronnych zainteresowaniach szczególną wagę przywiązywał do kwestii hipnozy. Uważał ją za znakomity sposób wniknięcia w psychikę ludzką w celu jej badania. Takie ukierunkowanie badawcze budziło w środowisku psychologicznym sprzeciw: do tej pory zwykło się uważać psychologię za dziedzinę filozofii (ibid.: 78), Ochorowicz zaś jako jeden z niewielu na ziemiach polskich dostrzegał jej związki z medycyną i skupiał się na badaniach w tym obszarze (ibid.: 73). Ogłaszane przezeń wyniki badań, wygłaszane na ten temat odczyty, a także próby zbudowania hipnoskopu, tj. przyrządu mającego mierzyć wrażliwość pacjentów na hipnozę (ibid.: 75), nie były brane poważnie przez środowisko lekarskie, które uważało hipnozę za szarlatanerię (ibid.: 73).

Co ciekawe, Ochorowicz interesował się również okultyzmem - znane są jego eksperymenty ze słynnym włoskim medium, Eusapią Palladino (Bodanko 2011: 226), z którą co niebagatelne - współpracował również Cesare Lombroso (Hołyst 1987: 33). Badacze ci zajmowali się również kryminologią - włoski naukowiec położył solidne podwaliny pod tę naukę, choć tok jego rozumowania nie zawsze okazywał się słuszny.

Nazwisko Lombroso pada tutaj nieprzypadkowo i będzie o nim mowa później; wątki okultystyczne nie pojawiają się w Wirach w sposób wyrazisty, jednakże warto wspomnieć, że i ta dziedzina ludzkich dociekań, jako sprzeciwiająca się naukom Kościoła, swego czasu została przypisana komunistom ${ }^{10}$. Wynika z tego, że zasadniczo wszelka aktywność, nieznajdująca aprobaty u gorliwych wyznawców katolicyzmu, która oferowała pogląd na świat odrębny od tego proponowanego przez religię, łatwo mogła zostać przypisana grupom dostrzegającym w nauce Kościoła sprzeczności czy wręcz wartości szkodliwe.

10 W 1920 roku, a więc zaledwie dziesięć lat po publikacji Wirów, ks. Kazimierz Wais, profesor Uniwersytetu Jana Kazimierza we Lwowie, wygłosił odczyt, w którym obalał tezy właściwe pewnemu popularnemu wówczas odłamowi spirytystów. Duchowny powoływał się nie tylko na ustalenia naukowe, ale argumentował swoje racje również za pomocą przykładów zjawisk nadprzyrodzonych i dokonań sławnych wówczas mediów. Zjawiska niewytłumaczalne były jego zdaniem efektem ciemnych sił, ewentualnie hipnozy, a najprawdopodobniej zwykłego oszustwa. Odczyt zakończył słowami: „Dodajmy do tego, że znaczny odłam spirytystów [...] hołduje socjalizmowi lub oświadcza się wprost za zupełnym komunizmem. Dlatego brońmy zmartwychwstałej Ojczyzny przed spirytyzmem!". Wypowiedź kapłana stanowi wyraz ugruntowanych zapewne od pewnego czasu skojarzeń zainteresowań parapsychologicznych z odejściem od modelu Polaka-katolika. Cyt. za: Sołowianiuk 2014: 55. 
Jak zapatrują się na kwestie poszukiwań tego, co niesamowite, poza naukami kościelnymi pozostali bohaterowie powieści? Warto poznać zdanie, jakie ma na ten temat umiarkowany Groński. Oto w rozmowie z nim Marynia przyznaje się, że Laskowicz przechwalał się w jej obecności swymi zdolnościami hipnotyzerskimi. Usłyszawszy to,

Groński zwrócił wzrok na drugi koniec stołu, w stronę studenta, i ujrzał jego oczy wytężone, upiorne i błyszczące, utkwione w pannę Marynię.

„Ależ - pomyślał - on istotnie próbuje na niej swojej siły”.

Więc zmarszczył brwi, a zwróciwszy się ku niej, rzekł:

- Tego, co jest hipnotyzm, naprawdę nikt dobrze nie wie. Widzi się objawy i nic więcej. Ale jak też tłumaczył go pan Laskowicz?

- Mówił to, co już dawniej słyszałam, że osoba uśpiona musi wykonać wszystko, co każe ten, który ją uśpił - i że nawet rozbudzona, zawsze mu podlega.

- To nieprawda! - odpowiedział Groński.

- I ja tak myślę. Utrzymywał przy tym, że i mnie potrafiłby bardzo łatwo uśpić, ja zaś czułam, że wcale nie.

- Doskonale! A czy takie rzeczy panią zajmują?

- Hipnotyzm mniej. Jak ma być coś tajemniczego, to wolę słuchać o duchach (W I 60-61).

Panna Zbyłtowska wyznaje wprawdzie, że lubi słuchać „o duchach”, ale nie świadczy to bynajmniej, by pasjonowało ją ich wywoływanie. Należy pamiętać, że Sienkiewicz był pod wielkim wpływem poetów epoki romantyzmu - co za tym idzie, wszelkie niesamowitości w jego utworach mają najczęściej romantyczną proweniencję i nie muszą się łączyć z modą na wirujące stoliki.

Hipnotyzm jawi się tu jako siła, której obawia się nawet zadeklarowany sceptyk Groński. Jednocześnie, jako nieznana, jest uważana za straszną i funkcjonującą na prawach tabu. Niestosowne wydaje się opowiadanie o niej dzieciom czy niedojrzałym panienkom, najlepiej w rozmowie z nimi tego typu zjawiska bagatelizować. Marynia wyczuwa jakiś dysonans w słowach Grońskiego i na jego deklarację, że wierzy on „w duszki, nimfy, w driady i w aniołów” (W I 62), odpowiada pytaniem: „Naprawdę? Bo pan mówi ze mną zawsze jak z dzieckiem" (W I 62).

Charakterystyczne od strony kompozycyjnej jest wtrącenie do rozmowy o hipnotyzmie tematu postaci fantastycznych wywodzących się z kultury ludowej (Marynia opowiada Grońskiemu, że bardziej od hipnotyzmu fascynują ją opowieści o skrzatach i rusałkach - stąd jego deklaracja). Znamienne pozostaje też włączenie postaci nadprzyrodzonych znanych z kultury chrześcijańskiej i użycie wobec nich nazwy w formie osobowej. Ten fragment powieści dobrze ilustruje pogląd, że „wyróżnikami przełomu wieków i początków wieku XX były światopoglądowy chaos i brak trwałych, duchowych punktów odniesienia” (Sołowianiuk 2014: 42). Zarazem dowodzi, że zarówno skuteczność hipnotyzmu, jak i praktyk religijnych czy opartych na starych, ludowych wierzeniach to tylko kwestia wiary i nie da się owej skuteczności raz na zawsze udowodnić bądź obalić, bo też „obalalność nie jest w zasadzie właściwym kryterium autentycznie empirycznego charakteru jakiegokolwiek przedsięwzięcia” (Cioffi 2010: 164).

Do tej pory zatem przewinami Laskowicza są bezgraniczna ufność w moc nauki oraz naginanie dla własnych niedwuznacznych celów sposobu pracy z ludzką psychiką, której tajniki nie zostały do tej pory zbadane (przy czym ów sposób jawi się dobitnie jako wysoce 
niepokojący, by nie rzec: niebezpieczny). Ten niedwuznaczny cel to uwiedzenie nieletniej będącej w stanie transu - czyli de facto gwałt na osobie pozostającej w stanie zawężenia pola świadomości.

Postać Laskowicza, z założenia płytka i uosabiająca wszystko to, co cechowało rewolucję zdaniem jej przeciwników, aby nie była zbyt szablonowa i nużąca, została obudowana kilkoma „ozdobnikami”. Młody socjalista jako czarny charakter to kolejny Inny, z którym polskie społeczeństwo szlacheckie nie chce się konfrontować na pokojowym gruncie, już na początku przyjmując wobec niego postawę pełną uprzedzeń i agresji. Laskowicz to jeszcze jeden bohater uosabiający lęk przed obcym, który przyjdzie, by rabować polskie majątki i gwałcić polskie kobiety - w galerii czarnych charakterów Sienkiewicza figuruje on wespół z Bohunem, Bogusławem, Azją czy odrażająco przedstawionymi Krzyżakami. Wspólna cecha wymienionych postaci to legitymowanie się tożsamością narodową inną niż polska, zaś religijną - inną niż katolicka (Azja nie jest nawet chrześcijaninem, tylko muzułmaninem). W kwestii pochodzenia społecznego i posiadanego majątku zachodzą tu pewne modyfikacje (nierzadko ubiegający się o pannę zły bohater jest bardzo bogaty), jednak żaden z nich nie może powiedzieć o sobie, że jest typowym polskim szlachcicem. Kolejny proces, jaki tu zachodzi, to niejako inkorporacja jednego podmiotu przez drugi. Ideologia „Polki dla Polaków" to wyraz uprzedmiotowienia bohaterek, które być może wybierają polskich bohaterów dlatego jedynie, że nie mają innego wyjścia. Czarne charaktery, mimo iż początkowo przedstawiane jako atrakcyjne, w końcu okazują się na tyle odstręczające, że nie sposób heroinom uznać je za partnerów.

Jest więc Laskowicz projekcją lęków braci szlachty, a może jej cieniem - wszak zanurzeni w patriarchalnym systemie bohaterowie Sienkiewiczowscy reprezentują typ mężczyzny szarmanckiego i rycerskiego; w gronie postaci usytuowanych po słusznej stronie tylko Krzycki otwarcie stosuje przemoc wobec kobiet.

Laskowicz, od kiedy jego poglądy polityczne zostają wyjawione $\mathrm{w}$ gronie gości Jastrzębia, jest przez nich postrzegany jako zły z natury. W swoim uprzedzeniu utwierdzają się oni za pomocą jednostkowych obserwacji fizjonomicznych. Oddaje się im również narrator. W opisywanej przezeń twarzy studenta przede wszystkim zwracają uwagę oczy „wytężone, upiorne i błyszczące” (W I 60). Pożądliwe spojrzenie Laskowicza napastuje i świdruje Marynię; student dosłownie rozbiera ją wzrokiem (W I 30). Takie wyraziste oczy są przypomnieniem oczu Bohuna, świecących w ciemnościach „jak dwa karbunkuly” (Sienkiewicz 1999: II, 24) i za pomocą tego odwołania ukierunkowują od razu interpretację postaci.

Agresywność spojrzenia to niejedyny aspekt wiążący się z oczyma Laskowicza. Również ich rozstaw i położenie względem pozostałych części twarzy ma w świecie powieściowym niebagatelne znaczenie. W rozmowie, jaką przeprowadza Groński z relegowanym z dworu studentem (obaj jadą tą samą dorożką do miasta; Groński chce tam zrobić zakupy), narrator zwraca uwagę, że przyjaciel Krzyckich, spojrzawszy na Laskowicza i „ujrzawszy jego oczy, osadzone blisko jedno przy drugim, pomyślał: »Nie!... Takie jednak oczy istotnie mogą patrzeć tylko przed siebie i nie są w stanie objąć szerszego widnokręgu «" (W I 88).

Groński utwierdza się w ten sposób w przekonaniu, że poglądy Laskowicza na sprawy społeczne są ograniczone i że optując za rewolucją, student tak naprawdę nie ma pojęcia o problemach ludu. Uwaga Grońskiego o oczach Laskowicza to wyraz potocznej wia- 
ry w zwierzęcość tych osób, których oczy osadzone są zbyt blisko lub daleko od siebie ${ }^{11}$. Bohater przyswoił sobie tę wiedzę zapewne za pośrednictwem teorii Lavatera i jego następców, które to teorie de facto nie były niczym więcej niż systematyką potocznych wyobrażeń o tym, w jaki sposób wygląd zewnętrzny stanowi wyraz charakteru człowieka (Skorupa 2013: 533).

Prace szwajcarskiego uczonego cechowały nieprecyzyjność i ogólnikowość (Bachórz 1976: 90). Jak się zdaje, głównym ich przesłaniem było wskazanie, że tylko człowiek o rysach idealnie harmonijnych ma charakter bez skazy - ideałem dla zurychskiego pastora był Chrystus (ibid.). Zasadniczo każde, najdrobniejsze nawet odstępstwo od przyjętego przez Lavatera kanonu było poczytywane jako wada i skaza charakteru osoby obdarzonej nieproporcjonalnymi rysami twarzy. Trudno powiedzieć, skąd owa obsesja u oświeceniowego badacza; najpewniej rozwinęła się ona na gruncie zapatrzenia w antyczny wzorzec kalokagatii, „albowiem przekonanie o bezpośrednim związku cielesnego kształtu człowieka z jego właściwościami duchowymi należy do bardzo starych w europejskim kręgu kulturowym” (ibid.: 88).

Oczy spoglądające złym wzrokiem, zbyt blisko osadzone obok siebie, to najjaskrawszy przykład wykorzystania przez Sienkiewicza teorii fizjonomicznych. Autor Wirów, w przeciwieństwie do Prusa, nie opisywał reakcji fizycznych bohaterów skrupulatnie, z odwołaniem do słownictwa medycznego, zaczerpniętego z dzieł Darwina (Skorupa 2013: 505). Portrety fizjonomiczne Sienkiewicza cechuje duża malarskość, a ich konstrukcja często zasadza się na stosowaniu różnorakich metafor i przywoływaniu odniesień kolorystycznych (ibid.: 482). Do zbudowania takiego portretu wystarcza mu częstokroć jedna charakterystyczna cecha, stanowiąca dominantę charakteryzacyjną postaci (ibid.: 499). Dobitnie widać to w przypadku Laskowicza, co do wyglądu którego czytelnik jest skazany na domysły.

Opierając się na kierunku wytyczonym przez fizjonomikę, można spróbować zanalizować drzemiącą w Laskowiczu skłonność do zła za pomocą wyników prac wspomnianego już Cesarego Lombrosa. Przekład jego Człowieka zbrodniarza, dokonany przez Jana Popławskiego, ukazał się nakładem wydawnictwa M. Wołowskiego w latach 1891-1892 i niewykluczone, że zapoznał się z tym wydaniem Sienkiewicz.

Głównym celem dzieła włoskiego kryminologa była klasyfikacja typów przestępców na podstawie ich danych antropometrycznych. Zdaniem Lombrosa odczytanie z rysów twarzy i proporcji sylwetki rodzaju przestępstwa, jakie osobnik mógłby popełnić, jest możliwe - i pozwoliłoby to zapobiegać przestępstwom w przyszłości. Wspomagając się obserwacjami i pomiarami ciał zbrodniarzy osadzonych w kilku zakładach karnych, Lombroso dokonał klasyfikacji zbrodniarzy ze względu na rodzaj popełnianych przez nich wykroczeń przeciw prawu oraz ich częstotliwość (tzn. odróżniał recydywistę od np. zabójcy w afekcie), osądził też, czy zbrodnie były długo planowane, czy np. zostały popełnione wskutek impulsu itd.

Współcześnie zarzuca się mu stosowanie niejasnej terminologii naukowej (Leszczyński 1989: 104) oraz dopasowywanie argumentów w taki sposób, aby zawsze potwierdzały z góry założoną przez niego tezę. Największe zastrzeżenia jego teorie - czy to urodzonego zabójcy, czy związku geniuszu i szaleństwa - budziły od strony etycznej: prowokowały one

\footnotetext{
11 Wiedzę tego rodzaju propagowano w popularnych poradnikach i leksykonach nawet u progu XXI wieku. Zob. np. Sabelanka 1991: 88.
} 
bowiem do segregacji ludzi i rościły sobie prawo do decydowania o ich „przydatności” dla społeczeństwa. Podobne podejście reprezentowali później naziści.

Większość teorii Lombrosa ma dzisiaj charakter historyczny. Docenia się wprawdzie jego wkład w rozwój psychologii (jako jeden z pierwszych badaczy dostrzegł związek między warunkami atmosferycznymi a samopoczuciem jednostki - Hołyst 1987: 22) i, rzecz jasna, kryminologii (prawnicy doceniają bądź co bądź jego spostrzeżenia mówiące o tym, że „przestępstwo nie zawsze jest wynikiem wolnej woli człowieka” - Leszczyński 1989: 104). Niemniej jednak trzeba pamiętać o tym, że

Diagnozy Lombrosa są powieleniem różnego rodzaju mniej lub bardziej publicznych opinii, są wspaniałym świadectwem XIX-wiecznych metod społecznego oceniania normalności ludzi. Do „skazania” wystarczała jakakolwiek niezgodność z rygorem moralności, zlekceważenie nacisku obyczaju i wreszcie opór prawu (Hołyst 1987: 30).

Te obiegowe opinie, z których korzystał Lombroso, obowiązywały również w kręgu bohaterów Sienkiewicza. Gdyby bowiem autor Wirów skonstruował scenę spotkania Laskowicza z Lombrosem, diagnoza profesora okazałaby się niekorzystna dla studenta. Włoski uczony twierdził - opierając się na badaniach Puglii i Palettiego - że „zboczenia w sferze uczuć są cechą charakterystyczną zbrodniarzy, jak również obłąkanych. Wielka inteligencja może łączyć się ze skłonnościami do zbrodni lub obłąkania, ale nigdy nieskazitelność uczuć” (Lombroso 1892: III, 27 - pisownia uwspółcześniona). Na zewnątrz uwidacznia się to w nietypowym układzie oczu: „Otóż anomalie czaszki odpowiadają zwykle zboczeniom inteligencji, zaś anomalie twarzy, a zwłaszcza oczu - zboczeniom w formie uczuciowej, które stanowią tak częstą, a nawet nieodłączną właściwość zbrodniarzy urodzonych" (ibid.).

Wynikałoby stąd, że Laskowicz jest istotą skażoną od urodzenia i przez cały czas drzemią w nim te cechy, które pewnego dnia pozwolą mu dokonać morderstwa. Narrator, ukazując go jako typowego socjalistę, może nieco gorączkowo i żarliwie wyznającego projekty swego ugrupowania, stara się przekonać czytelnika, że rewolucja przyciąga jednostki zdegenerowane. Świadczy o tym scena, w której zostaje postrzelony Krzycki (W I 120). Staje się to po stłumieniu strajku pracowników folwarcznych i po wymierzeniu kar „szkodnikom” niszczącym lasy Krzyckich. Leśnicy otrzymują wówczas „niezdarne listy z obietnicą, że »dostaną kulą w leb i dziedzic też«" (W I 119). Rewolucjoniści przedstawieni są tu jak zwykli opryszkowie, przed którymi mieszkańcy Jastrzębia bronią dworu, jakby spodziewając się najazdu.

Jednocześnie czytelnik jest przekonywany o tym, że nie wszyscy nisko urodzeni przynależą do zrywu. Przykład podaje doktor Szremski, skonstruowany trochę na podobieństwo Judyma:

Otóż dziś rano słyszałem urywek takiej rozmowy między moim famulusem a ślusarzem: ślusarz powiada - „Ja jestem socjalistą, to tam nie ma gadania!” - „Jak to nie ma gadania, mówi mój służący, to pan w Boga nie wierzy i Polski pan nie kocha?” - „A dlaczego ja mam nie wierzyć w Boga i Polski nie kochać?” - „Bo socjaliści nie wierzą w Boga i Polski nie kochają!” A ślusarz na to - „Tak, a to niech ich choroba tłucze!” - Oto w jaki sposób ludzie należą do socjalistów! Nie powiadam, że wszyscy, ale wielu! (W I 97) 
W świadomości bohaterów istnieje nieusuwalna rozdzielność między kochaniem Boga i kraju a akcesem do rewolucji. Sąd ten pozostaje w ciekawym stosunku do tez Lombrosa, który uważał, że znakomita większość przestępców (a za takiego winno się uważać Laskowicza na mocy dotychczasowych ustaleń) to osoby bardzo religijne, często bigoteryjne (ibid.: 78). Ich więź z Bogiem najczęściej przejawia się w tym, iż uważają go za swojego sprzymierzeńca i zarówno jego, jak i świętych proszą o pomoc w wykonaniu zbrodniczego planu. W ten sposób obala Lombroso powszechne mniemanie o ateizmie zbrodniarzy, „jakby religia była najpotężniejszym wędzidłem dla powstrzymania zbrodni” (ibid.).

Przekonania Sienkiewicza i narratora jego powieści są w tej kwestii odmienne. Laskowicz bowiem, razem z bratem wychowany przez samotną matkę handlującą dewocjonaliami, przez cały okres dzieciństwa miał kontakt z księżmi i Kościołem. Wiarę stracił później, w gimnazjum - a może nigdy jej nie miał, narrator bowiem wyraźnie sugeruje, że Kościól, z którym miał do czynienia, to Kościół powierzchownych praktyk i czczenia figurek. To Kościól, który indoktrynuje niepostrzeżenie i nie pozostawia pola do własnej interpretacji zachodzących w świecie zjawisk. Dobrze ilustruje to przykład księdza, który uroił sobie, że kupiony gdzieś na licytacji posążek, „istotnie bardzo ładny i misterny” (W I 71) to arcydzieło Canovy, przedstawiające świętą Apolonię. „Oczywiście, podziw kanonika podzielał organista, dzwonnik, cała służba kościelna i obaj chłopcy” (W I 72).

W tym kontekście trudno się dziwić brakowi wiary Laskowicza. Wydaje się, że narrator ów brak niejako usprawiedliwia. Kryje się tu również postulat, aby to, co oferuje Kościół, było wartościowe i umożliwiało wiernym autentyczne duchowe przeżycia. Jego język pełen jest bowiem skostniałych metafor, ogólna zaś nauka obiecuje szczęście w nieokreślonej przyszłości, po śmierci - podczas gdy socjalizm zachęca do pracy nad polepszeniem bytu za życia. Nie sposób rzecz jasna wywrócić całej doktryny chrześcijańskiej na nice, jednak Kościół powinien się postarać, by wygrać walkę propagandową ze świeżą, porywającą ide$\operatorname{ologią}^{12}$.

To, co wspólne dla wymowy tekstów Sienkiewicza i Lombrosa, ukazuje się natomiast $\mathrm{w}$ innej kwestii. Lombroso zwraca uwagę na poczucie misji wielu zbrodniarzy. Niezależnie od tego, w jaki dokładnie sposób kształtuje się ich stosunek do religii, uważają oni, że ich działalność doprowadza do likwidacji wielu niepożądanych zjawisk i osób w społeczeństwie (bogatych oszustów, krzywdzicieli dzieci itp.) ${ }^{13}$.

Ten fakt odpowiada w zupełności interpretacji rewolucji zawartej w Wirach. Z perspektywy narratora, jak również bohaterów należących do szlachty, przewrót socjalistyczny

\footnotetext{
12 Na pierwszy rzut oka trudno dostrzec tego typu sugestie w tekście powieści. Łatwiej o jej tendencyjne odczytanie, ukazujące wymowę Wirów jako jednolitą ideologicznie, wręcz stronniczą. Rewolucja jako kataklizm, forma zagłady świata chrześcijańskiego, sprzeciwiająca się „świętemu prawu własności” i wywracająca zastany, feudalny porządek jest interpretowana tak przez konserwatywnych czytelników i badaczy Sienkiewicza, którzy wymowę ideologiczną wszystkich powieści postrzegają jednoznacznie jako wyraz krytyki jakichkolwiek zmian i bohaterską obronę feudalnego status quo. Aprobatywny stosunek do tak interpretowanej postawy mają badacze posługujący się narzędziami teologii, jako argument za słusznością opowiadania się przeciw rewolucji podający to, że w świecie rządzonym przez chrześcijańskiego Boga nieunikniona jest hierarchia, widoczna nawet w organizacji bytów niebiańskich, a co dopiero ziemskich. Zob. np. Bielat 2012.

13 Lombroso 1892: III, 68. Lombroso wskazuje na specyficzne poczucie moralności i przestrzeganie norm etycznych przez przestępców, podając wiele barwnych przykładów. O tym, że ściśle określony kodeks funkcjonuje wśród łamiących prawo nawet i dzisiaj, wiadomo po lekturze jakiegokolwiek reportażu z zakładu dla osadzonych, opowiadającego o gnębieniu np. pedofili czy zabójców rodziców.
} 
to przecież nic innego jak rozbój maskowany szczytnymi hasłami nawołującymi do poprawy życia klas cierpiących niedostatek i wyzysk.

W pracy Lombrosa można znaleźć jeszcze kilka cech, pomocnych w zaklasyfikowaniu Laskowicza jako urodzonego przestępcy.

Najjaskrawsze z nich, jakie przyjdzie tu jeszcze wymienić, to szczególny stosunek złoczyńców do miłości. Zdaniem włoskiego uczonego bowiem „rzadko zbrodniarz wykazuje prawdziwą miłość do kobiet [...]. Miłość przestępcy jest cielesną i dziką. Jest to miłość wszeteczna [... ]" (Lombroso 1892: III, 53). O tym, w jaki sposób spogląda Laskowicz na pannę Marynię, była już mowa. Narrator tak silnie akcentuje fascynację studenta ciałem skrzypaczki, że czytelnikowi zdaje się umykać, iż „zachwycał się nią jak poetycką wizją” (W I 73). Zdanie to natychmiast jest uzupełnione konstatacją, że „ta wizja była zarazem młodą, uroczą jak wiosna dziewczyną" (W I 73). W tym kontekście warto zacytować tu dalszą część wywodu naukowca na temat relacji uczuciowych przestępców:

Niekiedy zresztą dosyć rzadko, nawet mordercy zwyczajni [... jak gdyby żywią uczucie jedyne i potężne, miłość prawdziwie idealną; ale powtarzam: są to wypadki nader rzadkie, którym nie możemy nadawać zbytniego znaczenia, jeżeli przypomnimy sobie [...] zdolność do udawania, jaką zbrodniarze doprowadzają do mistrzostwa (Lombroso 1892: III, 54).

Lombroso nie wierzy zatem w to, by jakikolwiek przestępca był zdolny wykrzesać z siebie jakiekolwiek głębokie odczucia. Narrator Sienkiewicza, zdaje się, również nie pokłada nadziei w tym, by w Laskowiczu drzemały uczucia wyższe. Ale czy tak jest na pewno?

Gdy się dokładniej wczytać w treść powieści - choćby w końcowe jej rozdziały - widać wyraźnie, że Laskowicz cierpi z powodu niemożności widywania Zbyłtowskiej (W II 264), a pobicie przez Władysława za to, że złamał zakaz zbliżania się do dziewczyny, przelewa czarę goryczy:

- Pan Krzycki prawdziwy pan! Zbił mnie przed chwilą kijem za to, żem się ośmielił do niej przemówić.

I począł się śmiać przez zaciśnięte zęby (W II 270).

Spiskując z zakochaną w Krzyckim bez pamięci Polcią, służącą panny Anney, której chłopskie pochodzenie stało się już wszystkim wiadome, student zobowiązuje się pomóc rozgoryczonej i zazdrosnej pokojówce. Czytelnik wie już, iż urządziła swojej pracodawczyni scenę, wyzywając ją od chamek i oświadczając, że więcej pracować dla niej nie będzie. Polcia prosi Laskowicza o pomoc w uniemożliwieniu małżeństwa tych dwojga. Kiedy student, nienawidzący z całego serca Krzyckiego (podejrzewał go swego czasu o awanse względem Maryni) niedwuznacznie daje do zrozumienia, że nie będzie problemem zamordowanie szlachcica, służąca stanowczo protestuje.

W kolejnej odsłonie czytelnik widzi pokój, w którym Zbyłtowska przygotowuje się do koncertu charytatywnego. Naraz okazuje się, że na ulicy zgromadził się groźny i rzucający wyzwiskami tłum, który po chwili wdarł się do mieszkania. W zamieszaniu demolowane są pomieszczenia i wynoszone sprzęty; tłum, „złożony z chrześcijan, a w części z żydów” (W II 272), cuchnący wódką, wykrzykuje: „Precz z utrzymanką!” (W II 272). W pewnym momencie, nie wiadomo skąd, pada strzał i dosięga skrzypaczki. 
Mija kilka godzin; do stróża kamienicy, w której nastąpiło to zajście, podchodzi jakiś człowiek i pyta o zdrowie Maryni. Dowiaduje się, że zmarła i odchodzi. Rankiem zostaje odnalezione ciało Laskowicza z przestrzeloną piersią.

Wynika stąd, że kula, która trafiła Marynię, była przeznaczona dla panny Anney, a Laskowicz, pozbawiony obiektu adoracji, traci sens życia. Choć planował morderstwo, efekty jego strzału okazały się zupełnie nieoczekiwane i może nie tyle zmieniły kwalifikację czynu w sensie prawnym, co znacząco wpłynęly na odczucia studenta po dokonanym zabójstwie. Lombroso podkreśla, że urodzeni mordercy nie mają wyrzutów sumienia i nie przyjmują do wiadomości, że zrobili coś nagannego (Lombroso 1892: III, 67); gdyby Laskowicz zabił pannę Anney, czytelnik byłby skłonny zgodzić się z klasyfikacją jego jako człowieka złego z natury. Nieumyślne postrzelenie panny Zbyłtowskiej staje się jednak czymś w rodzaju zabójstwa w afekcie; jak powiada Lombroso, wówczas wyrzuty sumienia w bardzo wielu przypadkach doprowadzają do tego, że morderca sam również pozbawia się życia (ibid.: 37).

Narrator Sienkiewicza ukazuje w ten sposób zawodność wszelkich klasyfikacji i dowodzi, że różnorodność charakterów ludzkich jest zbyt wielka, by dało się je pogrupować w schematy. To myślenie dalekie od dziewiętnastowiecznego scjentyzmu, łudzącego tym, że wszystko da się zbadać i opisać.

Choć bohaterowie Wirów ze wszystkich sił starają się nie dopuścić do upadku ich świata, całą powieść przenika nawracająca raz po raz konstatacja, że ten świat w końcu musi zginąć. Muszą skończyć się gwałty pana na chłopkach; musi nadejść koniec zależności kobiet od mężczyzn i traktowanie ich jak przedmiotu, którym mogą rozporządzać wedle ich woli; niedorzecznością wkrótce będzie zawieranie małżeństw z przyczyn majątkowych; i wreszcie nie może być tak, by jedni byli syci, a drudzy głodowali.

Wiry obrazują przeczucie nadchodzących zmian; zarazem akcentują jednak, że nie wiadomo, czego się po nich spodziewać - i będą one budziły strach dopóty, dopóki wszystkie warstwy społeczeństwa nie będą chciały współpracować podczas tworzenia nowego modelu i dopóki działania jednej grupy będą wynikały z chęci zemsty na grupie drugiej.

\section{Bibliografia}

Bachórz, Józef 1976. „Karta z dziejów zdrowego rozsądku, czyli o fizjonomice w literaturze”. Teksty 2: 86-105.

Bielat, Andrzej 2012. Ocalić Europę. Henryk Sienkiewicz - apologeta chrześcijaństwa i obrońca cywilizacji tacińskiej. Sandomierz: Wydawnictwo Diecezjalne i Drukarnia.

Bodanko, Anatol 2011. „Julian Ochorowicz (1850-1917) - ojciec polskiej psychologii naukowej”. Nauczyciel i Szkoła 2 (50): 223-229.

Burdziej, Bogdan 2010. „Żydzi w listach Henryka Sienkiewicza”. W: Bogdan Burdziej, Ewa Owczarz (red.). Sienkiewicz dzisiaj. Formy (nie)obecności. Toruń: Wydawnictwo Naukowe Uniwersytetu Mikołaja Kopernika. 221-281.

Cioffi, Frank 2010. Freud i pseudonauka. Tłum. Ryszard Stachowski. Kraków: Wydawnictwo WAM.

Hołyst, Brunon 1987. „Cesare Lombroso. Jego czasy i dzieło”. W: Cesare Lombroso. Geniusz i obtakanie. Warszawa: Państwowe Wydawnictwo Naukowe. 7-34. 
Koziołek, Ryszard 2010. Ciała Sienkiewicza. Studia o ptci i przemocy. Katowice: Wydawnictwo Uniwersytetu Śląskiego.

Krzyżanowski, Julian 1968. Henryka Sienkiewicza żywot i sprawy. Warszawa: Państwowy Instytut Wydawniczy.

Leszczyński, Juliusz 1989. „Geniusz i obłąkanie, Cesare Lombroso, Warszawa 1987 (recenzja)”. Palestra 33/11-12 (383/384): 102-104.

Lombroso, Cesare 1892. Człowiek - zbrodniarz w stosunku do antropologii, jurysprudencji i dyscypliny więziennej. Zbrodniarz urodzony. Obłąkaniec umystu moralnego. T. III. Tłum. Jan Ludwik Popławski. Warszawa: M. Wołowski.

Łapiński, Wojciech 2016. „Sienkiewicz a religia. Małżeństwo z rozsądku?”. W: Maciej Gloger, Ryszard Koziołek (red.). Sienkiewicz polityczny. Sienkiewicz religijny. Warszawa: Wydawnictwo DiG. 251-162.

Łobaczewska, Stefania 1984. Beethoven. Kraków: Polskie Wydawnictwo Muzyczne.

Markiewicz, Henryk 1981. „Postać literacka i jej badanie”. Pamiętnik Literacki 72/2: 147-162.

Nowak-Bobrowska, Wanda 1971. „Julian Ochorowicz na drogach i bezdrożach psychologii”. Kwartalnik Nauki i Techniki 16/1: 67-85.

Sabelanka, Ewa 1991. W encyklopediach nie znajdziecie, czyli mini leksykon rzeczy śmiesznych, poważnych i osobliwych. Poznań: Krajowa Agencja Wydawnicza.

Sienkiewicz, Henryk 1999. Ogniem i mieczem. Bielsko-Biała. 1990. Wiry. Gdańsk: Graf.

Skorupa, Ewa 2013., Twarze, emocje, charaktery. Literacka przygoda z wiedza o wygladzie człowieka. Kraków: Wydawnictwo Uniwersytetu Jagiellońskiego.

Sobieraj, Tomasz 2004. „Sienkiewicz i muzyka”. Ruch Literacki XLV, 6 (267): 591-608.

Sołowianiuk, Paulina 2014. Jasnowidz w salonie, czyli spirytyzm i paranormalność w Polsce międzywojennej. Warszawa: Wydawnictwo Iskry.

Tyszka, Adam 2007. „Sienkiewicz i wiry rewolucji”. W: Krzysztof Stępnik, Tadeusz Bujnicki (red.). Henryk Sienkiewicz w kulturze polskiej. Lublin: Wydawnictwo Uniwersytetu Marii Curie-Skłodowskiej. 289-296. 